\title{
The Application of Data Mining by using K-Means Clustering Method in Determining New Students' Admission Promotion Strategy
}

\author{
Agustina Heryati, Muhammad Izman Herdiansyah
}

\begin{abstract}
This study aims to determine the promotion strategy on the admission of new students at the university. Universities need appropriate promotion strategies to increase the number of new students enrolled in subsequent years and to fulfill the equal distribution of new students in each region and study programs at the University. Classification of new student data reception at the Indo Global Mandiri University (IGM University) in 2018/2019 uses the CRISP-DM data mining application (the Cross-Industry Standard Process for Data Mining) using the K-Means grouping method. Research data using primary and secondary data. The population and sample of the study were 1011 students using 4 (four) attributes in this study, namely the name of the student, the area of origin, the study program, and the promotion strategy (direct visit, word of mouth, media, brochures, and coming directly). This test is carried out with the Waikato Environment for Knowledge Analysis (WEKA) 3.8 tool. The results of this study indicate that the direct visit strategy is the most appropriate in the admission of new students at IGM University, amounting to 492 students with $26 \%$, with this strategy being able to absorb many new student candidates from various regions including Palembang, Regency / City, and regions in outside South Sumatra, there is also equality in various study programs at IGM University. Word of mouth promotion strategies and media are optimized to be included in the promotion team in determining the promotion strategies in the following year to increase the number of new student admissions.
\end{abstract}

Keywords : Promotion strategy, data mining, K-Means clustering, new students' admission

\section{INTRODUCTION}

Mo odern and sophisticated information technology in all fields has developed very fast and advanced in the fields of economy, industry, education, communication and information and promotion.

Application of information technology in the field of Promotion can help manage valuable and useful information so that it has its own added value to be achieved with what is desired both for Universities that are facing competition in

Revised Manuscript Received on February 05, 2020.

* Correspondence Author

Agustina Heryati, Master of informatics Universitas Bina Darma/ Management Informatica Universitas IGM, Palembang, Indonesia, Email: agustina.heryati@uigm.ac.id

*Muhammad Izman Herdiansyah, Master of informatics Universitas Bina Darma, Palembang, Indonesia Email: m.herdiansyah@binadarma.ac.id

(C) The Authors. Published by Blue Eyes Intelligence Engineering and Sciences Publication (BEIESP). This is an open access article under the CC BY-NC-ND license (http://creativecommons.org/licenses/by-nc-nd/4.0/) the business world. promotion is the main tool for the success of an organization / university in attracting the attention of consumers. (Adefulu, 2015). Promotion requires the right

plan so that everyone who is a target or promotion target of the University is realized so that competitiveness can also be increased in each region where there is an equal distribution

of students. Promotion strategies are based on consumer behavior, in the form of desires for what is offered by organizations / universities in the form of products or services. (Chaharsoughi and Yasory, 2012) IGM University is the largest private tertiary institution in Palembang which has 4 (four) faculties, namely the Faculty of Computer Science, the Faculty of Economics, the Faculty of Engineering, and the Faculty of Government and Culture. Each faculty has a study program that can be an option for new students New Student Admission Activities at IGM University are activities that are held regularly for new students. IGM University continues to improve the quality of facilities, lecturers, employees, administration, buildings, facilities, etc., but some obstacles are not related to the number of new student admissions so that the emergence of private universities and other high schools around the South Sumatra region so that the very tight competition made the University of IGM recruit new students to continue to plan the right strategy to determine the promotion strategy so that the number of new students enrolled in each year is obtained. Collection of student data obtained from historical data, so the data is obtained every year continuously. Large data will extend the search for information from several groups based on the characteristics of the data at the University, forming some grouping of student data so that it can determine an effective and efficient promotion strategy for the University. (Ong, 2013), (Nuswantoro, Rima and Ramadhani, no date), (Hülya Güçdemir Hasan Selim, 2015). The number of students dropping out due to inappropriate use of promotional strategies will affect the number of new students at tertiary institutions. (Puspa et al., 2014). Large data can be implemented using data mining. Data Mining is designed to discuss data (usually large amounts of data - usually related to business) to find patterns that match the reinforcement pattern which is translated into a new subset. (Hajizadeh, Ardakani, and Shahrabi, 2010) Grouping of student acceptance data is grouped using K-Means Clustering, grouping data into several clusters based on the similarity of the data so that the relevant data are also grouped by the same cluster and the same have different characteristics which are grouped in other clusters that have the same similarity.

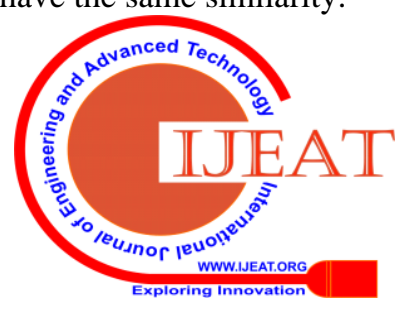


K-Means Clustering has the advantage of being able to make large data groups quickly and efficiently to be able to make decisions in determining a very effective promotional strategy the following year.

(Kashwan and Velu, 2016), (Kusuma, 2017), (Asril, Wiza and Yunefri, 2015).

To meet the number of new student admissions in each quarter, this study is to analyze and process student data in the previous year from IGM University, in determining the results of the information on promotion strategies in the following year. The data attributes that will be used in this study are the name of the student, promotion strategies that include media, direct visits, brochures/banners/banners, word of mouth, and coming directly, from the area of students and study programs that are expected to help and help increase the promotion team IGM University in conducting research New students from various regions in Indonesia specifically in the South Sumatra region. Processing these data attributes using the WEKA (Waikato Environment for Knowledge Analysis) application tool for determining promotional strategies at the IGM University. (Tiwari, Jha and Yadav, 2012). The problem that can be formulated in this background is the title of this research is the Implementation of Data Mining for Promotion Strategy for Admission of New Students using the K-Means Clustering Algorithm.

\section{FRAMEWORK FOR THINKING}

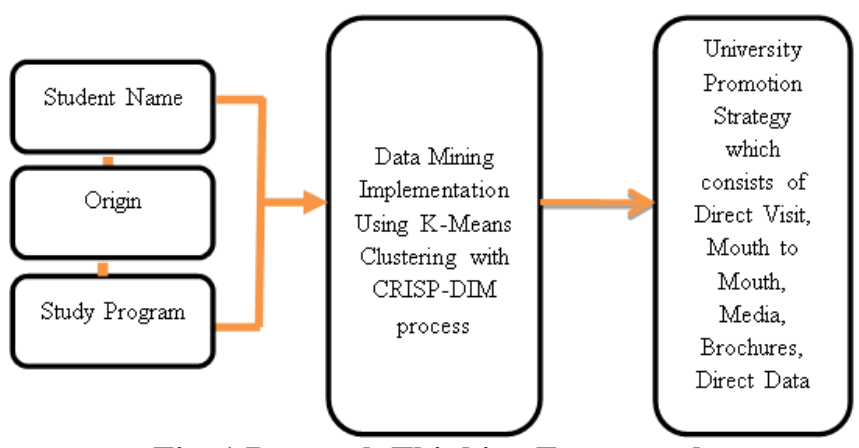

Fig. 1 Research Thinking Framework

\section{METHODOLOGY}

This study uses a qualitative method. In this study, the population and study sample were all New Student Admissions at IGM University in 2018/2019, totaling 1011 students.

Research data using primary data and secondary data Primary data in this study were obtained using direct interviews with the head of Student Affairs, Alumni, and Job Fair as well as the IGM University Promotion team. Secondary data used in this study are data collected from data on the admission of new students who have re-registered at IGM University.

The data analysis technique of the data mining method used in this experiment uses the Cross-Industrial Standard Model for Data Mining (CRISP-DM) which consists of six phases Asril, E., Wiza, F. And Yunefri, Y. (2015), Hermawati, F. A. (2018) namely:

a. Business Understanding Phase

b. Data Understanding Phase

c. Data Processing Phase (Data Preparation Phase) d. Modeling Phase

e. Evaluation Stage

f. Placement Phase

\section{ANALYSIS RESULTS}

\section{A.Business Understanding Phase}

- Determining the Purpose of a Business (Research)

Determination of the business The study was based on data on prospective students in 2018/2019 who requested the number of new students in 2019/2020 at IGM University. Processed data improves the quality of service in the promotion section as preliminary information obtained as one of the bases in taking results in determining an effective promotion strategy for the admission of new students the following year at IGM University.

- Situation Assessment

IGM University is one of the private universities in Palembang which has 13 S1 and D3 study programs including Management study programs (S1), Accounting (S1), Information Engineering (S1), Information Systems (S1), Computer Engineering ( S1), Civil Engineering (S1), Architectural Engineering (S1), Urban Area Planning (PWK) (S1), Government Science (S1), Visual Communication Design (DKV) (S1), English v (S1), Surveys and Monitoring (D3), and Information Management (D3).

- Purpose of Data Mining

The purpose of data mining in determining the promotion strategy can find the proposed profile:

- Determination of the profile of prospective students who will register at IGM University.

- Determine the Promotion Strategy based on preparations from the profile of prospective new students in 2018/2019.

\section{B. Data Understanding Phase}

\section{- Data Collection}

At the data reception hearing, there will be an initial (raw) admission of new students in 2018/2019 at IGM University The data comes from promotional data managed by the Bureau of Student Affairs, Alumni, and the IGM University Job Fair. Data is collected at the time new prospective students re-register by filling in the re-registration form at IGM University.

\section{- Data Description}

The data used in this study are prospective students from secondary/vocational / MA schools located in Palembang, Regency / City, and regions outside South Sumatra. In 2018/2019, prospective new students were arrested by 1011 students. Preliminary data for admission of new students come from the names of students, school origin, regional origin, study programs with D3 and S1 levels, and promotion strategies.

\section{- Evaluation of Data Quality}

To produce data sources carried out through the data mining process, using a database of new student admissions for the 2018/2019 school year. 
The data is evaluated first through interviews with the IGM University promotion team and several new student candidates from various origin areas and study programs and then the data is processed using the

working-work-together-work methods. will be used in this study.

\section{- Attribute Selection}

The new student admission dataset in 2018/2019 after assessing the quality of the data, the selection of attributes of this study consisted of the attribute number of new student admission data for the 2018/2019 school year admission of 1011 students.

\section{Data Preparation Phase}

\section{- Data Selection}

Student selection data in this study came from admission data for new students in the 2018/2019 acceptance of 1011 students at IGM University. This preliminary data is done as a selection data for the selection of attributes in this study. These attributes include Student's Name, Regional Origin, Study Program, Promotion Strategy (Direct Visit, Mouth to Mouth, Media, Brochures and Direct Data).

- Initial Data Processing

Initial data processing organizes selected data to perform a data processor. Initial data processing was obtained from prospective new students in 2018/2019 who had re-registered at the University of IGM which increased 1011 students, then the data was used Microsoft Excel, then the data was selected to be used as research attribute data, find the data processed by using data mining, k-means clustering algorithm with the WEKA tool.

- Data transformation

Data is grouped with nominal types such as origin, the Study Program must first initialize the data into a numerical form (Ong 2013 and Ramdhani 2014). To initialize the origin of the area and the study program can be seen from the steps below:

- Initialization of Regional Origin

In the Regional origin data, the regional division will be divided into three parts, namely:

- Palembang City

Palembang Palembang City consists of several sub-districts in Palembang, namely ilir barat sub-district 1, ilir barat sub-district 2, ilir timur sub-district 1, ilir timur sub-district 2, kalidoni sub-district, and the opposite of ulu sub-district. Regency / City

Regencies/cities located in the South Sumatra region are Banyuasin, Musi Banyuasin, Sekayu, Ogan Ilir, Prabumuli, Ogan Konering Ilir, Ogan Komering Ulu, Empat Lawang, Baturaja, Lahat, and Lubuk Linggau

- Outside South Sumatra

Outside South Sumatra Includes Bengkulu, Lampung, Jambi, Jakarta, Bogor, Bandung, Padang, Medan, Surabaya
Table- I: Regional Origin Initialization

\begin{tabular}{|c|c|c|}
\hline Origin & frequency & Initialization \\
\hline 1 & 717 & $\begin{array}{c}\text { Palembang } \\
\text { city }\end{array}$ \\
\hline 2 & 241 & $\begin{array}{c}\text { Regency / } \\
\text { City }\end{array}$ \\
\hline 3 & 53 & $\begin{array}{c}\text { Outside } \\
\text { South } \\
\text { Sumatra }\end{array}$ \\
\hline
\end{tabular}

Data sources: processed data for 2018/2019

The table below is an initiation of a study program that has been processed using a dataset of prospective new students in 2018/2019.

Table- II: Initialization Origin for Prospective Students of New Students in 2018/2019

\begin{tabular}{|c|c|c|c|}
\hline $\begin{array}{c}\text { Data } \\
\text { to }\end{array}$ & Origin & Study Lecture & $\begin{array}{c}\text { Promotion } \\
\text { Strategy }\end{array}$ \\
\hline 1 & 1 & $\begin{array}{c}\text { Technical } \\
\text { Information }\end{array}$ & Direct visit \\
\hline 2 & 1 & $\begin{array}{c}\text { Technical } \\
\text { Information }\end{array}$ & Direct visit \\
\hline 3 & 1 & $\begin{array}{c}\text { Technical } \\
\text { Information }\end{array}$ & Direct visit \\
\hline 4 & 1 & $\begin{array}{c}\text { Technical } \\
\text { Information }\end{array}$ & $\begin{array}{c}\text { Mouth to } \\
\text { mouth }\end{array}$ \\
\hline 5 & 2 & $\begin{array}{c}\text { Technical } \\
\text { Information }\end{array}$ & $\begin{array}{c}\text { Mouth to } \\
\text { mouth }\end{array}$ \\
\hline 6 & 1 & $\begin{array}{c}\text { Technical } \\
\text { Information } \\
\text { Technical } \\
\text { Information }\end{array}$ & $\begin{array}{c}\text { Direct visit } \\
\text { Mouth to } \\
\text { mouth }\end{array}$ \\
\hline 7 & 2 & $\begin{array}{c}\text { Technical } \\
\text { Information }\end{array}$ & $\begin{array}{c}\text { Mouth to } \\
\text { mouth }\end{array}$ \\
\hline 8 & 1 & $\begin{array}{c}\text { Technical } \\
\text { Information }\end{array}$ & $\begin{array}{c}\text { Mouth to } \\
\text { mouth }\end{array}$ \\
\hline 9 & 2 & $\begin{array}{c}\text { Technical } \\
\text { Information }\end{array}$ & Media \\
\hline 10 & 3 & Agustring & \\
\hline
\end{tabular}

Data sources: Wirta Agustin1, Erlin2 (2016), Rima Dias Ramadhani (2014).

- Study Program Initialization

The Study Program is given an initialization based on the frequency of the number of students in the study program. The results of the initialization can be seen in the table below:

Table- III Data Transformation for Study Programs

\begin{tabular}{|l|c|c|}
\hline \multicolumn{1}{|c|}{ Origin } & Frequency & Initialization \\
\hline $\begin{array}{l}\text { Information } \\
\text { Management }\end{array}$ & 165 & 1 \\
\hline $\begin{array}{l}\text { Information } \\
\text { System }\end{array}$ & 150 & 2 \\
\hline Accounting & 104 & 3 \\
\hline Civil Engineering & 102 & 4 \\
\hline
\end{tabular}


The Application of Data Mining by using K-Means Clustering Method in Determining New Students' Admission Promotion Strategy

\begin{tabular}{|l|c|c|}
\hline $\begin{array}{l}\text { Technical } \\
\text { Information }\end{array}$ & 81 & 5 \\
\hline Computer system & 80 & 6 \\
\hline $\begin{array}{l}\text { Visual } \\
\text { communication } \\
\text { design }\end{array}$ & 69 & 7 \\
\hline $\begin{array}{l}\text { Public } \\
\text { administration }\end{array}$ & 66 & 8 \\
\hline $\begin{array}{l}\text { Information } \\
\text { Management }\end{array}$ & 43 & 10 \\
\hline $\begin{array}{l}\text { Urban Area } \\
\text { Planning }\end{array}$ & 37 & 11 \\
\hline English & 21 & 13 \\
\hline $\begin{array}{l}\text { Survey and } \\
\text { Mapping }\end{array}$ & 37 \\
\hline $\begin{array}{l}\text { Architectural } \\
\text { Engineering }\end{array}$ & 59 \\
\hline
\end{tabular}

Data sources: Data promotion for 2018/2019

The next step is to move the initial data to the initial data before the data is ready to be processed. Below is data that has been initialized based on the Study Program:

Table- IV: Initialization Study Programs for

Prospective Students of New Students in 2018/2019

\begin{tabular}{|c|c|c|c|}
\hline $\begin{array}{c}\text { Data } \\
\text { to }\end{array}$ & Origin & $\begin{array}{c}\text { Study } \\
\text { Programs }\end{array}$ & Promotion Startegy \\
\hline 1 & 1 & 5 & Direct visit \\
\hline 2 & 1 & 5 & Direct visit \\
\hline 3 & 1 & 5 & Direct visit \\
\hline 4 & 1 & 5 & Mouth to mouth \\
\hline 5 & 2 & 5 & Mouth to mouth \\
\hline 6 & 1 & 5 & Direct visit \\
\hline 7 & 2 & 5 & Mouth to mouth \\
\hline 8 & 1 & 5 & Mouth to mouth \\
\hline 9 & 2 & 5 & Mouth to mouth \\
\hline 10 & 3 & 5 & Media \\
\hline 11 & 2 & 5 & Mouth to mouth \\
\hline 12 & 2 & 5 & Mouth to mouth \\
\hline 13 & 2 & 5 & Mouth to mouth \\
\hline 14 & 2 & 5 & Media \\
\hline
\end{tabular}

Data sources: processed data for 2018/2019

\section{D.Modeling Phase}

Modeling is the phase in the use of data mining by determining the algorithm that will be used in this research. The determination of the algorithm used is k-means grouping which will manage the dataset of prospective new students at IGM University using the WEKA tool.

- Selection of Modeling Techniques

Modeling on the WEKA tool is a means to model data for new student admissions in 2018/2019 using the k-means clustering algorithm.

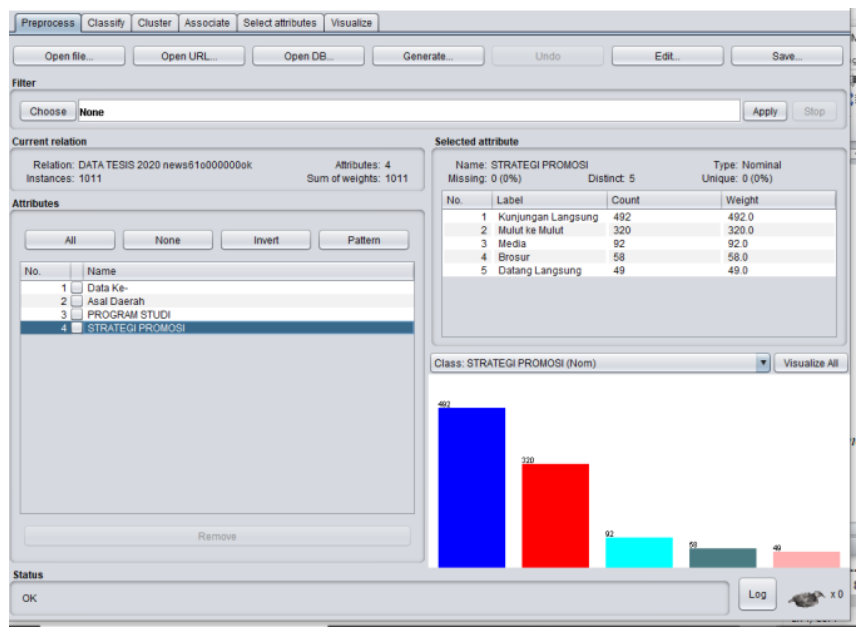

Fig. 2 Modeling Data with The WEKA tool

Figure explain modeling with the WEKA tool for promotion strategy data Direct visits with a count of 492, Mouth to Mouth with a count of 320, a Media with a count of 92, a Brochure with a count of 58, and Come directly with a count of 49.

- Flowchart k-means Clustering Algorithm

- Determination of the Number of Clusters

Determination of the number of clusters used as many as 5 clusters $(k=5)$, to find out information from the results of the promotion by determining the strategy of direct visit promotion, media to mouth, media, register and come directly.

Table-V Each Midpoint Cluster Starts

\begin{tabular}{|c|c|c|c|}
\hline $\begin{array}{c}\text { Central } \\
\text { Starting } \\
\text { Point }\end{array}$ & Origin & $\begin{array}{l}\text { Study } \\
\text { Programs }\end{array}$ & $\begin{array}{l}\text { Promotion } \\
\text { Strategy }\end{array}$ \\
\hline $\begin{array}{c}\text { Cluster } \\
0\end{array}$ & 1 & 1 & Media \\
\hline $\begin{array}{c}\text { Cluster } \\
1\end{array}$ & 5 & 2 & $\begin{array}{c}\text { Mouth to } \\
\text { mouth }\end{array}$ \\
\hline $\begin{array}{c}\text { Cluster } \\
2\end{array}$ & 1 & 2 & Brochure \\
\hline $\begin{array}{c}\text { Cluster } \\
3\end{array}$ & 6 & 12 & Direct Visit \\
\hline $\begin{array}{c}\text { Cluster } \\
4\end{array}$ & 1 & 1 & $\begin{array}{c}\text { Come } \\
\text { directly }\end{array}$ \\
\hline
\end{tabular}

Data sources: processed data for 2018/2019

- Determine the cluster center point (Random)

Determine the starting point of a cluster or centroid is determined randomly or randomly, from the dataset of prospective new students amounted to 1011 students with the number of clusters 5 (cluster 0 - cluster 4) consisting of direct visits, word of mouth, media, brochures, and direct dating. Cluster value 0 is taken from student data 394, cluster value 1 in student data 211 and student data 2 clusters 2, student data cluster 3 811, student data cluster 4,490.

Calculate the Distance of Each Data with the Euclidean Distance formula

- Calculations for Cluster 0

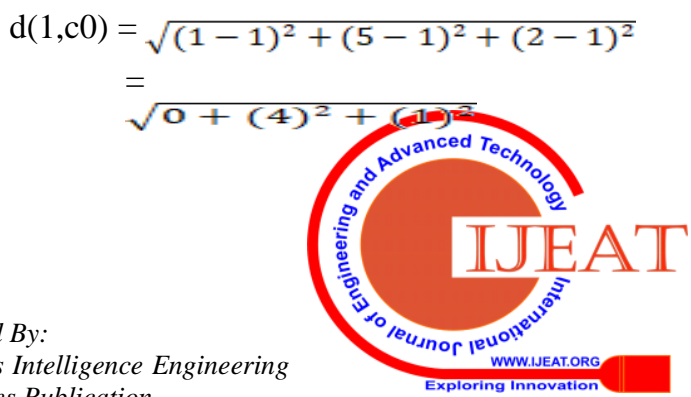

Retrieval Number: C5414029320 /2020@BEIESP DOI: 10.35940/ijeat.C5414.029320 Journal Website: www.ijeat.org 
- Calculations for Cluster 1

$$
=\sqrt{16+1} \sqrt{17}=4,12
$$

$$
\begin{aligned}
\mathrm{d}(1, \mathrm{c} 1) & =\sqrt{(1-2)^{2}+(5-2)^{2}+(2-2)^{2}} \\
& =\sqrt{(1)^{2}+(3)^{2}+0}=\sqrt{1+9}=\sqrt{10} \\
& =3,16
\end{aligned}
$$

- Calculations for Cluster 2

$$
\begin{aligned}
\mathrm{d}(1, \mathrm{c} 2) & =\sqrt{(1-1)^{2}+(5-2)^{2}+(2-1)^{2}} \\
& =\sqrt{0+(3)^{2}+(1)^{2}}=\sqrt{9+1}=\sqrt{10} \\
& =3,16
\end{aligned}
$$

- Calculations for Cluster 3

$$
\begin{aligned}
d(1, c 3) & =\sqrt{(1-2)^{2}+(5-12)^{2}+(2-4)^{2}} \\
& =\sqrt{(1)^{2}+(7)^{2}+(2)^{2}}=\sqrt{1+49+4} \\
& =\sqrt{54}=7,34
\end{aligned}
$$

- Calculations for Cluster 4

$$
\begin{aligned}
\mathrm{d}(1, \mathrm{c} 4) & =\sqrt{(1-1)^{2}+(5-1)^{2}+(2-1)^{2}} \\
& =\sqrt{0+(4)^{2}+(1)^{2}}=\sqrt{16+1} \\
& =\sqrt{17}=4,12
\end{aligned}
$$

- Data Grouping based on Distance with Center Point Grouping based on minimum distance to the center of the cluster by giving the code " 1 " Generate data up to 1011 towards the center of the cluster.

Table-VI Closest Distance to the Origin Center Area

\begin{tabular}{|c|c|c|c|c|c|}
\hline C0 & C1 & C2 & C3 & C4 & $\begin{array}{c}\text { Minimum } \\
\text { Value }\end{array}$ \\
\hline 4,12 & 3,16 & 3,16 & 7,35 & 4,12 & 2 \\
\hline 4,00 & 3,32 & 3,00 & 7,68 & 4,00 & 3 \\
\hline 4,00 & 3,32 & 3,00 & 7,68 & 4,00 & 3 \\
\hline 4,47 & 3,32 & 3,61 & 7,14 & 4,47 & 2 \\
\hline 4,24 & 3,00 & 3,32 & 7,28 & 4,24 & 2 \\
\hline 4,00 & 3,32 & 3,00 & 7,68 & 4,00 & 3 \\
\hline 4,24 & 3,00 & 3,32 & 7,28 & 4,24 & 2 \\
\hline 4,12 & 3,16 & 3,16 & 7,35 & 4,12 & 2 \\
\hline 4,24 & 3,00 & 3,32 & 7,28 & 4,24 & 2 \\
\hline 4,24 & 3,00 & 3,32 & 7,28 & 4,24 & 2 \\
\hline 4,24 & 3,00 & 3,32 & 7,28 & 4,24 & 2 \\
\hline 4,24 & 3,00 & 3,32 & 7,28 & 4,24 & 2 \\
\hline 4,90 & 3,32 & 4,12 & 7,14 & 4,90 & 2 \\
\hline 4,58 & 3,16 & 3,74 & 7,07 & 4,58 & 2 \\
\hline
\end{tabular}

Data sources: processed data for 2018/2019

The figure below explains the process of grouping data at the minimum closest distance to the center point by looking at the minimum value in table 4.10 by giving the initials " 1 " in cluster 0 , initials " 2 " in cluster 1 , initials " 3 " in cluster 2, initials " 4 "in cluster 3 , the initials" 5 "in cluster 4 . To achieve the value of drinking by repeating 7 times.

- WEKA testing tool

Creating a new student dataset for the 2018/2019 school year generates data consisting of:

- Android cluster values and cluster instances

- Graph clustering of student positions in each cluster respectively

Explain it:

1. Students with Regional Origin $=1$ for cluster 0 and Students with Study Program $=1.4474$ for cluster 0 (23\%)

2. Students with Origin Area $=2.2155$ for cluster 1 and Students with Study Program $=3.7759$ for cluster 1 (23\%)

3. Students with Regional Origin $=1$ for cluster 2 and Students with Study Program $=6.5282$ for cluster 2 (14\%)

4. Students with Regional Origin $=1.2453$ for cluster 3 and Students with Study Program $=9.4528$ for cluster $3(26 \%)$

5. Students with Regional Origin $=1$ for cluster 4 and

\begin{tabular}{|c|c|c|c|}
\hline Origin & & $\begin{array}{c}\text { Study } \\
\text { Program }\end{array}$ & \\
\hline Palembang & 53 & Acounting & 7 \\
\hline Bandung & 2 & English & 3 \\
\hline $\begin{array}{l}\text { Bangka } \\
\text { Belitung }\end{array}$ & 1 & DKV & 7 \\
\hline Batam & 1 & IP & 4 \\
\hline
\end{tabular}
Students with Study Program $=3.4792$ for cluster 4 $(14 \%)$

\section{E. Evaluation Phase}

Classes for 492 student direct promotion groups, 320 student mouth-to-mouth promotion strategies, 92 student promotion media strategies, 58 student brochure promotion strategies, and 49 students coming in person.

\section{F. Dissemination Phase}

- Cluster Results 0

Cluster 0 is a promotion strategy using media, we can see in the table below the results of the analysis of cluster 0 :

Table-VII Cluster Results 0 


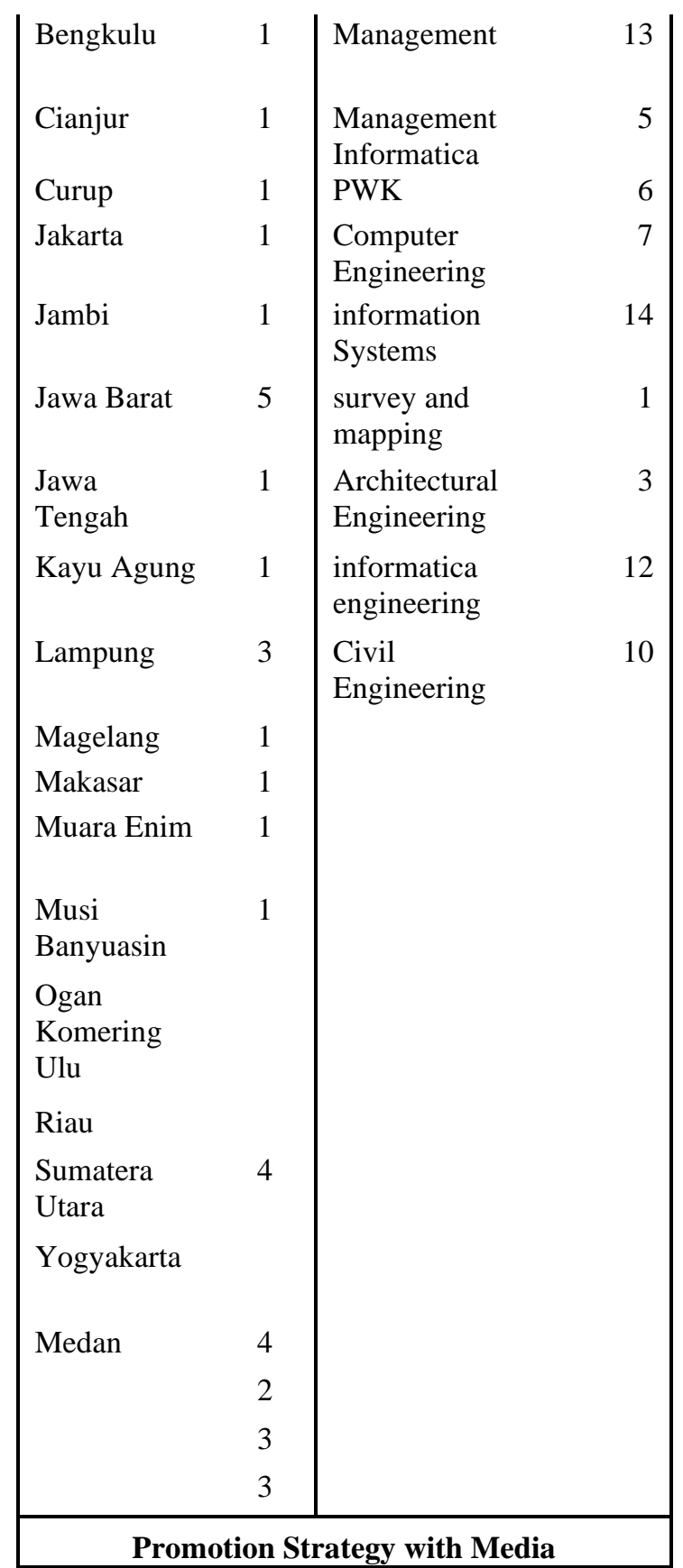

Data sources: processed data for 2018/2019

Cluster 0 results consisted of 92 students from the regions of Palembang, Regency / City and Outside South Sumatra. Promotion strategy with the Media, the distribution based on the origin of the most dominant regions are students who come from regions outside South Sumatra and some Regencies / Cities. For the promotion strategy using the media of student dissemination based on study programs, it is still not evenly distributed in each study program. Several study programs need to be held to increase the number of students, such as surveying and mapping, architectural techniques, and English. Then it can be concluded the results of the analysis that the implementation of promotional strategies with media based on regional origin or study programs can be further optimized because the media is currently one of the fastest promotion strategies. After all, it has a very broad reach so that prospective new students outside South Sumatra or city Regency can increase the number of new student admissions in the following year as well as equal distribution of the number of students in each study program at IGM University.

- Cluster Results 1

In Cluster 1 is a promotion strategy using mouth to mouth, we can see in the table below the results of the analysis of cluster 1 :

Table-VIII Cluster Results 1

\begin{tabular}{|c|c|c|c|}
\hline Origin & & Study Program & \\
\hline Palembang & 101 & Accounting & 40 \\
\hline Bangka Belitung & 1 & English & 13 \\
\hline Banyuasin & 29 & DKV & 13 \\
\hline Curup & 1 & IP & 25 \\
\hline Empat Lawang & 2 & Management & 55 \\
\hline Jambi & 11 & $\begin{array}{l}\text { Management } \\
\text { Informatica }\end{array}$ & 20 \\
\hline Jawa Barat & 1 & PWK & 12 \\
\hline Kayu Agung & 8 & computer Engineering & 24 \\
\hline Lahat & 9 & information Systems & 44 \\
\hline Lampung & 2 & survey and mapping & 10 \\
\hline Lubuk Linggau & 8 & $\begin{array}{l}\text { Architectural } \\
\text { Engineering }\end{array}$ & 7 \\
\hline Muara Enim & 31 & informatica engineering & 25 \\
\hline Musi Banyuasin & 30 & & \\
\hline Musi Rawas & 4 & Civil Engineering & 32 \\
\hline Ogan Ilir & 10 & & \\
\hline Ogan Komering Ilir & 17 & & \\
\hline $\begin{array}{l}\text { Ogan Komering } \\
\text { Ulu }\end{array}$ & 18 & & \\
\hline Pagaralam & 1 & & \\
\hline Pali & 5 & & \\
\hline Prabumulih & 8 & & \\
\hline Riau & 1 & & \\
\hline Sekayu & 20 & & \\
\hline Sumatera Utara & 1 & & \\
\hline Yogyakarta & 1 & & \\
\hline
\end{tabular}

Data sources: processed data for 2018/2019

Cluster 1 results consisted of 320 students from the regions of Palembang, Regency/City and Outside South Sumatra. Promotion strategy through Mouth to Mouth, the distribution based on the origin of the most dominant regions are students who come from Regencies/Cities and Palembang city areas and the distribution of students based on study programs have been evenly distributed in each study program. Then it can be concluded the results of the analysis that the implementation of the promotion strategy Mouth to Mouth based on regional origin and the study program needs to be improved again because word of mouth is the most effective and efficient strategy from the point of promotion costs. For this reason, IGM University is making improvements in terms of facilities, educators (lecturers), Student Creativity Unit so that the talents of these students are channeled. So that the promotion strategy by mouth was reached in the following year.

- Cluster Results 2

In Cluster 2 is a promotion strategy using a brochure, we can see in the table below the results of the analysis of cluster 2: 
Table-IX Cluster Results 2

\begin{tabular}{|lc|lc|}
\hline \multicolumn{1}{|c|}{ Origin } & & Study Program & \\
Palembang & 40 & Accounting & 3 \\
Banyuasin & 5 & English & 1 \\
Lampung & 2 & DKV & 2 \\
Musi & 6 & IP & 9 \\
Banyuasin & & & \\
Ogan Ilir & 4 & Management \\
Riau & 1 & 7 \\
Management & 4 \\
Informatica & \\
PWK & 2 \\
computer & 5 \\
Engineering & 14 \\
information & $\begin{array}{l}\text { Systems } \\
\text { survey and } \\
\text { mapping } \\
\text { Architectural } \\
\text { Engineering } \\
\text { informatica } \\
\text { engineering } \\
\text { Civil } \\
\text { Engineering }\end{array}$ \\
\hline Promotion Strategy with brochure \\
\hline
\end{tabular}

Data sources: processed data for 2018/2019

Cluster 2 results consisted of 58 students distributed through brochures based on the regional origin, the most were students from the Regency / City and Palembang city areas, while the distribution of students based on study programs was not evenly distributed in each study program. Then it can be concluded the results of the analysis that the implementation of promotional strategies with brochures based on regional origins and study programs were further enhanced. The brochure must be able to describe the overall promotion of the University itself. Brochures should be made as attractive as possible and the contents are clear and detailed. So that when students read it, they immediately understood what was explained in the brochure. The brochure is an effective promotion strategy because an explanation of the university has been included in the brochure both the study program and future directions on the chosen study program, its facilities, costs, and testimonials.

- Cluster Results 3

In Cluster 3 is a promotion strategy using direct visits, we can see in the table below the results of the analysis of cluster 3:

Table-X Cluster Results 3

\begin{tabular}{|lc|lr|}
\hline \multicolumn{1}{|c|}{ Origin } & & \multicolumn{2}{|c|}{ Study Program } \\
Palembang & 474 & Accounting & 50 \\
Banyuasin & 5 & English & 20 \\
Musi & 6 & DKV & 45 \\
Banyuasin & & & 28 \\
Ogan Ilir & 7 & IP & 80 \\
Prabumulih & 1 & Management & 26 \\
& & Management Informatica & 23 \\
& & PWK & 38 \\
& & computer Engineering & 64 \\
& & information Systems & 22
\end{tabular}

\begin{tabular}{|l|lr|} 
& Architectural Engineering & 10 \\
& informatica engineering & 41 \\
& Civil Engineering & 45 \\
\hline Promotion Strategy with direct visits
\end{tabular}

Data sources: processed data for 2018/2019

Cluster 3 results consisted of 492 students. The distribution using direct visit promotion strategies based on regional origin was mostly students from Palembang, while the distribution of students based on study programs was evenly distributed in each study program. Then it can be concluded the results of the analysis that the promotion strategy with Direct Visits based on regional origin and study programs needs to be applied to the Regency / City and outside Palembang so that the distribution is evenly distributed to the Regency / City and outside South Sumatra because direct visits are a strategy of "picking up the ball ". This strategy can interact directly with prospective new students so that the promotion team can be more convincing and provide clear information about the strengths of the university so that there is an increase in the number of students in the following year.

- Cluster Results 4

In Cluster 4 is a promotion strategy using coming directly, we can see in the table below the results of the analysis of cluster 4:

Table-XI Cluster Results 4

\begin{tabular}{|c|lc|}
\hline $\begin{array}{c}\text { Origin } \\
\text { Palembang }\end{array}$ & \multicolumn{1}{|c|}{ Study Program } \\
& Accounting & 4 \\
& DKV & 2 \\
& Management & 10 \\
& Management Informatica & 1 \\
& computer Engineering & 6 \\
& information Systems & 14 \\
& Civil Engineering & 12 \\
\hline \multicolumn{2}{|c|}{ Promotion Strategy with coming directly } \\
\hline
\end{tabular}

Data sources: processed data for 2018/2019

Cluster 4 results consisted of 49 students, the distribution using promotion strategies came directly based on the regional origin, the most were students from Palembang, while the distribution of students based on study programs was not evenly distributed in each study program. Then it can be concluded the results of the analysis that the promotion strategy with Come Directly based on regional origin and the study program needs to be improved again. Come directly is a business strategy that does direct marketing to prospective new students by way of prospective students coming directly to the university to see firsthand about the facilities provided by the university and hear directly about the University's image and the study program that will be taken by the prospective student.

\section{DISCUSSION}

\section{A.Direct Visits Promotion Strategy}

Promotion strategy of direct visits obtained the results of the analysis of the spread of students totaling 492 students with a percentage of $26 \%$ from various regions including 
Palembang, Regency / City, and outside South Sumatra and various study program options. Direct visits are a very appropriate strategy in the admission of new students at IGM University. IGM University has implemented a direct visit promotion strategy and has given significant results in increasing the number of new student admissions in 2019/2020. The direct visit is to record the schools that will be visited, then after being recorded the promotion team makes a direct visit to the schools. The Direct Visit Promotion Strategy can directly communicate, interact and convey information about the general description of the University of IGM clearly to prospective new students, including facilities, teaching staff (lecturers), employees, 13 Study Programs at IGM University and the direction of the objectives of each study program, This Student Creativity Unit (UKM) aims as a forum for IGM University students to channel their interests and talents as well as testimonials (alumni). The choice of study programs has been evenly distributed in each study program by using a direct visit promotion strategy. This strategy can influence prospective new students to join the University of IGM students.

The results of this study are supported by according to Simester, D., Characterization, A. D. And Sirnester, D. (2007) The activities of a promotion by carrying out activities included in marketing communication through personal marketing, while according to Cui, B., Yang, K. And Chou, T. (2016) explains that the activity of conveying information from the seller to buyers by influencing attitudes and behavior, where the University's promotion team will notify directly to the target consumer, that a good product is available in the right place at the right price.

\section{B. Mouth to Mouth Strategy}

The results of the analysis of the study of mouth-to-mouth promotion strategies amounted to 320 students with a percentage of $23 \%$ spread across various regions including Palembang City and Regency / City and various study program choices. Word of mouth promotion strategy is a strategy that tells the experience of buying a product or service to others by indirectly promoting the product. This strategy is very effective because word of mouth promotion is one of the communication channels that can be applied at the University by maintaining the quality of the products and services offered so that it can reduce the cost of promotion and facilitate promotion is also able to provide benefits for the University. IGM University for word-of-mouth promotion strategies needs to be implemented more optimally by improving the quality of education / teaching, research and community service. For the choice of study programs have been evenly distributed in each study program by using the mouth to mouth promotion strategy. So this mouth-to-mouth promotion strategy can be used as input to the University of IGM to be applied in the promotion strategy in the following year. The results of this study are supported according to research (Sari and Gusti, 2017) stating that the mouth-to-mouth strategy can increase the trust of the community, especially prospective new students in terms of the level of satisfaction and the quality of the quality given or offered. According to ('Page 1', 2006), "word of mouth promotion strategy is a way of promotion through word of mouth recommendations regarding the quality of a product." buy so that they can share their experiences about the product or service with others so that the customer implements a promotion that can attract the interest of other customers who listen to the conversation. According to (Brand et al., 2017) the stronger the mouth-to-mouth promotion strategy carried out, the attitudes of prospective new students will be formed. If communication is a positive thing then the attitude will be formed also positive. Conversely, if things are negative, then the attitude formed is also negative.

\section{C.Media Promotion Strategy}

The promotion strategy with the media showed the results of an analysis of 92 students with a percentage of $23 \%$ resulting in the distribution of students in districts / cities and outside South Sumatra and various study program choices. Promotion strategy with the media is a strategy that uses a communication tool such as electronic and print. Promotion Strategy through the media one effective and efficient promotion strategy in terms of time. IGM University has implemented a promotion strategy through the media, namely media in the form of IGM TV, IGM Radio, Social Media Instragram of IGM University, but IGM University has not been optimal in utilizing the strategy, IGM University must be able to maximize the use of available media in order to reach areas far from the city of Palembang. The choice of study programs has not been evenly distributed in each study program using the media promotion strategy, for this reason an increase was made using the media promotion strategy. so as to increase the number of new student admissions in the following year. The results of this study are supported according to research from stating that businesses that are marketing products or services with internet media can communicate products, which will be promoted, and sell goods and services via the internet. According to Hasanah, N. Et Al. (2015), (Untari and Fajariana, 2018) explained that Instagram media is one of the social media that has a big and important influence on a business. And (Zarrella, no date) social media marketing is a strategy of promotional activities through social media sites such as Facebook, Twitter, Youtube and so on. Social media is one of the right ways to promote products and services through internet marketing. The method is simple but has an amazing effect.

\section{D.Brochure Promotion Strategy}

The brochure promotion strategy obtained the results of an analysis of 58 students scattered in various cities of Palembang and Regency / city and various study program options. Promotion strategy using brochures is a strategy that markets through printed tools both on banners / billboards / brochures. This promotion strategy at IGM University has been implemented by creating brochures, billboards and banners that can help the promotion team section is distributed or placed in strategic places but not yet optimal because the brochure submitted is not yet in detail and clearly depicts IGM University with 13 study programs including directions Job analysts obtained from each study program, as well as brochures made for each study program so that they can broadly know the information conveyed through the brochure. 
The choice of study programs has not been evenly distributed in each study program by using the brochure promotion strategy, for it to be improved using the brochure promotion strategy. For this reason, promotion strategies with brochures can increase the number of new student candidates in the following year.

The results of this study are supported according to research from (Untari and Fajariana, 2018) advertising promotions are made in billboards, banners, leaflets, posters, brochures, branding cars, banners, and stickers that are placed in strategic places and describe in detail.

In addition, the promotion team also advertises in print and electronic media, although in limited quantities. According to (Muali et al., 2019) states in a company choose to do business worship through promotions that use print media such as newspapers, brochures, banners and others.

\section{E.Promotion Strategies Come Directly}

The promotion strategy came directly based on the results of the analysis stating that 49 students were dominant in the Palembang city area with a wide choice of study programs. Direct promotion strategy is a direct marketing strategy with prospective new students who come directly to the University of IGM to see the facilities and find out information directly coming to the University of IGM. The choice of study programs has not been evenly distributed in each study program by using the Direct Coming Promotion Strategy, for this reason an improvement is made using the Direct Coming Promotion Strategy, so there will be an increase in the following year.

The results of this study are supported according to research from (Wibowo and Event, 2015) the strategy of coming directly or personal selling is an interaction between individuals, face to face with the aim of reporting, improving, mastering, or maintaining mutually beneficial relationships with other parties. According to (Sopandi and Preliminary, 2011) states that this strategy opens the opportunity for the University to know the reactions of customers quickly, thus ensuring the seller to do the marketing mix (marekting mix) of the University by meeting the needs of each target market.

\section{CONCLUSIONS AND SUGGESTION}

\section{A.Conclusions}

- From the research that has been conducted the grouping of student data for the 2018/2019 school year through the distribution of regional origin and Study Programs based on promotion strategies using K-Means clustering Five clusters. For zero clusters with 92 students with Media promotion strategy, cluster one with 320 students with mouth-to-mouth promotion strategies, cluster two with 58 brochure promotion strategy students, cluster Three with 492 students with Direct Visit promotion strategies, and cluster Four with Number of 49 student promotion strategies Come Directly.

- The promotion strategy for the admission of new students at IGM University is based on the cluster formed in the 2018/2019 new admissions dataset which is a direct visit promotion strategy of 492 students with $26 \%$, word of mouth number of students 320 students with $23 \%$, media number of students 92 students with 23\%, the brochure numbered 58 students with $14 \%$ and came directly the number of students $49 \%$ with $14 \%$. The right promotion strategy at IGM University is a direct visit with 492 students with 26\%. Direct visits include the origin of the city of Palembang, Regency / City, and regions outside South Sumatra. The study program is evenly distributed in each of the most dominant study programs namely management and information systems due to the large number of high school students majoring in social studies and vocational school who come from the city of Palembang.Promotion strategy through direct visits and word of mouth is the right strategy in the selection of study programs due to the equal distribution of promotion strategies in the choice of study programs. As for the Media, come in person and brochures for the promotion strategy of the study program choice are prioritized so that there will be equity in each study program in the following years.

- Word of mouth and media promotion strategies are strategies that will become alternative promotional strategies that need to be optimized in the following year, because the mouth-to-mouth and media strategy is a very appropriate strategy because it can reduce the cost of university promotion and will increase the number of prospective new students as well as equal distribution in the regency. / Cities and regions outside South Sumatra the following year.

\section{B. Suggestion}

- Grouping of student data 2018/2019 IGM University should be done routinely the following year to improve the quality of promotional data so that it becomes the right decision for the next year's promotion strategy.

- This research can be used as a reference for the IGM University Promotion team to make decisions in conducting promotion strategies for prospective new student admissions.

\section{REFERENCES}

1. Adefulu, A. D. (2015) 'Promotional Strategy Impacts On Organizational Market Share And Profitability', 11(6), Pp. 20-33.

2. Agustin, W. (2016) 'Implementasi Metode K-Means Cluster Analysis Untuk Memilih Strategi Promosi Penerimaan Mahasiswa Baru', (Snik), Pp. 9-15.

3. Asril, E., Wiza, F. And Yunefri, Y. (2015) 'Analisis Data Lulusan Dengan Data Mining Untuk Mendukung Strategi Promosi Universitas Lancang Kuning', 6(November 2015), Pp. 24-32.

4. Chaharsoughi, S. A. And Yasory, T. H. (2012) 'Effect Of Sales Promotion On Consumer Behavior Based On Culture', 6(1), Pp 98-102. Doi: 10.5897/Ajbm11.739.

5. Cui, B., Yang, K. And Chou, T. (2016) 'Analyzing The Impact Of Price Promotion Strategies On Manufacturer Sales Performance', Journal Of Service Science And Managemen, 9(April), Pp. 182-187.

6. Hasanah, N. Et Al. (2015) 'Analisis Efektivitas Iklan Jejaring Sosia Sebagai Media Promosi Menggunakan Epic Model', 2(2), Pp. 99-110.

7. Hermawati, F. A. (2018) 'Data Mining', (January 2013).

8. Hülya Güçdemir Hasan Selim (2015) 'Industrial Management \& Data Systems Article Information':, 115(6), Pp. 1022-1040. Doi: Http://Dx.Doi.Org/10.1108/Imds-01-2015-0027 Downloaded.

9. 'Lupiyoadi' (2006), p. 2006.

10. Kashwan, K. R. And Velu, C. M. (2016) 'Customer Segmentation Using Clustering And Data Mining Techniques', 5(January 2013). Doi: 10.7763/Ijcte.2013.V5.811. 
11. Kusuma, D. T. (2017) 'Prototipe Komparasi Model Clustering Menggunakan Metode K-Means Dan Fcm Untuk Menentukan Strategi Promosi : Study Kasus Sekolah Tinggi Teknik-Pln Jakarta', 3(June 2015), Pp. 0-10. Doi: 10.13140/Rg.2.2.35612.08326.

12. Muali, C. Et Al. (2019) 'Pemasaran Syariah Berbantuan Media Sosial : Kontestasi Strategis', 05(April), Pp. 168-185.

13. Nuswantoro, U. D., Rima, O. And Ramadhani, D. (No Date) 'Data Mining Menggunakan Algoritma K-Means Clustering Untuk Menentukan Strategi Promosi', Pp. 1-9.

14. Ong, J. O. (2013) 'Implementasi Algoritma K-Means Clustering Untuk Menentukan Strategi Marketing', (April), Pp. 10-20.

15. Puspa, Y. Y. Et Al. (2014) 'Mahasiswa Baru Pada Upbjj-Ut Palu Di Wilayah Propinsi Sulawesi Tengah Terbuka Khususnya Unit Program Belajar', 3(4), Pp. 281-288.

16. Sari, G. G. And Gusti, G. E. (2017) 'Penerapan Strategi Word To Mouth Dalam Sistem Jual Beli Di Kelompok Pengajian Salafi Kota Pekanbaru', 5(1), Pp. 17-26.

17. Simester, D., Characterization, A. D. And Sirnester, D. (2007) 'Note Optimal Promotion Strategies ':, 43(2), Pp. 251-256.

18. Sopandi, E. And Pendahuluan, A. (2011) '( Tinjauan Atas Kegiatan Promosi Pts Di Jawa Barat Tahun 2010 )', (April), Pp. 87-101.

19. Tiwari, M., Jha, M. B. And Yadav, O. (2012) ““ Performance Analysis Of Data Mining Algorithms In Weka ", 6(3), Pp. 32-41.

20. Untari, D. And Fajariana, D. E. (2018) 'Strategi Pemasaran Melalui Media Sosial Instagram ( Studi Deskriptif Pada Akun @ Subur_Batik )', 2(2), Pp. 271-278.

21. Wibowo, A. And Event, S. P. (2015) 'Arie Wibowo : Strategi Promosi Event ......', 14(02), Pp. 180-191.

22. Zarrella, D. (no date) The social Media Marketing Book.

\section{AUTHORS PROFILE}

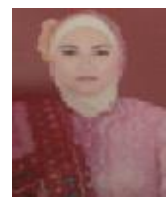

Agustina Heryati. She is Lecturer at Universitas Indo Global Mandiri, Palembang, Indonesia. Her Research interests include Data Mining, System Modeling, Business Intelligence, information technology, etc. She has many publications in international journals, and conferences in fields of interest

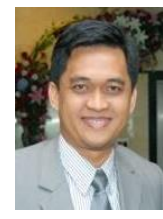

Muhammad Izman Herdiansyah. is a Lecturer at Universitas Bina Darma, Palembang, Indonesia. His research interests include Data Mining, System Modeling, Network Optimization, Business Intelligence, and Information Technology. He has 20 years teaching experiences in informatics department as well as several research projects. 